\title{
The Value Development and Narrative Features of Children's Film
}

\author{
Yin Xiaoli \\ Silk Road School of Art, Weinan Normal University, Weinan, Shanxi, 714099
}

Keywords: Children's Movies, Typification, Value Development, Narrative Features

\begin{abstract}
The first audience of children's films is children. Compared to non-children's audiences, children audiences seem to have single aesthetic experience, which is more jumping than non-children's audiences and the aesthetic experience is also flowing. The aesthetic experiences of non-children's audiences are relatively stable and have formed a certain solidification mode that cannot easily be changed. Therefore, the types of children's films should be rich and diversified so as to conform to the ever-changing nature of children. This paper explores various types of children's films to find their value for development, in order to provide recommendations for children's films.
\end{abstract}

\section{Introduction}

Compared with adults, children have intuitive and understanding of relatively weak. So if a movie wants to favorite children audience, it should be attractive in the plot. It does not mean that the more complex episodes will make Children audience happy. In fact, this complex plot led to the audience unable to grasp the main line of the story, thereby losing interest in watching. Children's physical and mental development is still in the development stage, so creators need to use rich means to build the plot [1].

\section{The Type of Children Movies and Their Value}

\subsection{Torn family children's movies}

Family environment is a major objective environment for children. All kinds of psychological development of children reflect the characteristics of the family environment, and the family environment also plays a restrictive role in the psychological development of children. In children's movies, there is also increasing concern for the content of single-parent families. With the aim of focusing on the current situation and psychological needs of children living in the disabled families, it is recognized that the impact of the fragmentation of families on children's physical and mental health is huge. Joey and his brother grew up in a single-parent home in the U.S. film "Out of the Child." The brother wanted to go out and play with her classmates, but it happened that her mom was going to see her grandmother in the field. Therefore, he had to take care of his younger brother at home. His mother said: "Why did your daddy die so early?" Make kids acting as fathers at home when they were young, but these seem to have little impact on younger Joey. His brother is his dad, but prank convinced him that he had killed his brother. He could not stand the fact that his brother "dead". All this shows that children from single-parent families are more vulnerable. Of course, there are still many movies of such children with incomplete families, such as " Childhood on the roof" "orz boy" "mother did not go far" "San Mao goes to the army" "only the mother of the world is good" "with you"and so on. Fortunately, there are such movies to help children cry to the bottom of their heart, to show the community what they need, but also to explore a discussion of the development of children in disabled families. These children's families concerned about the impact of the disability of the family. However, in the process of narration, the theme is deviated from the theme. The problem between parents becomes the focus of the film. It is worth noticing and avoiding that the children have misunderstandings when they are watching. 


\subsection{Inter-generational relationship between children's movies}

Due to many reasons, such as the death of a parent, divorce and being too busy with work, many children grow up with relatives who have inter-generational relationships because the elderly and children are basically the same in their mentality and thinking. Therefore, the common language will be more enough and they get along well with each other. However, due to the differences in the times, the two intergenerational generations will have a stage of friction and misunderstanding. However, they will eventually be understood in virtue of common understanding. A large number of such films have also appeared in children's films, such as "Butterflies" "Young Ladies" "Little Tomatoes" "Both of us" and so on. These all reveal the psychological characteristics of children's different growth environments through movies. We know the habit of respecting and treating the elderly around in the viewing process. The Korean children's movie "Love - Going Back" has touched a large audience. It not only inspires children in the film, but also makes adults feel the true love in movies. Mother decided to send Xiang Yu to the countryside to find a job for convenience. Grandmother can not speak, nor reads. He can not adapt to the rural life, because there is even no battery for the game machine. So, he started to express his dissatisfaction with the action. But such a boy before leaving, shyly handed his hand-painted postcards to the illiterate grandmother, so that he can know the grandmother's well-being after returning to the city. The film focuses on the grandmother and grandchildren's affection. Although her grandmother can not speak, she expresses her love for her grandchildren through her actions. With a faint eyebrow, her grandchildren compared their lives in the cities and the countryside, which make children's audiences to learn to cherish the things. And they can immediately do whatever their own things, but also understand the " The tree wants to be quiet, the son wants to raise but not to stay. ". Family relationship has always been a common topic of mankind, and more and more cities in today's population aging also appeared in the "empty nest phenomenon" and other meditating status quo. It is worth our pondering over the various problems that have arisen when the two generations have been put together. However, the gratifying relations that have emerged have also made people feel happy.

\subsection{Rural children's movies and left-behind children's movies}

China is a country with big differences between the rich and poor. The quality and level of life of children in urban and rural areas are different. The movies reflecting the living conditions of rural children are gradually getting more and more. The problem of food and clothing in rural areas can not be solved but the knowledge is still eager. They Want to have the same reading conditions as urban kids, and many editors focused their attention on children in rural life, revealing the audience's contemplation with a simple cinema language. There are a group of special children in the town of Tangjiahui in the old district of Dabie Mountains in Anhui Province. Many of their parents work in the big city for many years, and most of them are housed in relatives' homes. They use broken tables and chairs and textbooks in classes, live in shabby dorm rooms, and go back to the mountain road every for a dozen years. The school does not have any sports and entertainment facilities, and they eat rice every day with pickles. They are known as "left-behind children". These children have a life without parental care, and exercise self-reliance life ability. "Ma Dong's Holiday" is China's first movie focusing on the status quo of left-behind children. "Staying behind" is a spiritual symbol - loneliness, lack of communication, and forgotten. Going beyond this kind of suffering not only depends on external conditions, but more importantly needs inner awakening and strength. Growth is such a strength. Ma Dong chooses growing other than collapse, with a strong personal growth to solve the pain left behind. The choice of his father, Ma Fugui, was defined as "the pain of liberalism". After the land of China was blown by the wind of civilization, the awareness of being an ontology "human" began to awaken and people began to pursue the right to subsistence and emotion that one should enjoy. Ma Fugui wanted to preserve his right to choose a happy life, but his choice of being responsible for his own life had to bear moral and ethical criticism. Therefore, left-behind children always have a different mind from ordinary children's minds, and how to capture the psychological state of such different children is also the reason behind the filming of left-behind children's directors[2]. 


\section{The Narrative Features of Children's Films}

Since the founding of New China in 1949, Chinese children's films have ushered in new opportunities for development. Away from the frequent war, the filming of Chinese children's movies has better external conditions. The utilitarianism of literature, the beginning of the founding of new China, the period of Qin and Han Dynasties, such as "poetic teachings" and "music education", the historical period of "literary and art revolution" during the "Cultural Revolution", the disorganization of reform and opening up and the commodity tide at the turn of the century, these all combine to make Chinese children's films show a complex pattern.

\subsection{The narrative mode is modeled}

The film from the very beginning of the founding of New China to the "Cultural Revolution" was greatly influenced by the pattern of literary creation in its period. The performance is that many films follow the similar "routine" to narrate, so that people just know the beginning of the story, they can know what will happen next. The result is that the audience is led by the narrative's nose and greatly lost its subjectivity. Such as "fishermen" tells that, in the late Qing Dynasty, a lonely old fisherman put up a fishing basin, and the fish in the basin help him hit a lot of fish every day. It was targeted by county magistrate, he and the missionaries together coercion and lure him to surrender the fishing basin. The old fisherman would rather smash the fishing basin than pay it out, and finally the fishing basin was robbed. It turned into a windy wave, and covered the county magistrate and missionaries. The characters in this story follow the binary opposition between good and evil, and narrative follows the pattern of justice over evil. Such model is very common at the time, and "Havoc in Heaven" "God Pen Ma Liang" is its representative. The symbol of the feudal rulers of the Jade Emperor was disturbed by the Monkey King. Since the reform and opening up to the present, the pattern of Chinese children's films has not yet completely changed. This is certainly related to the Chinese's habit of accepting but also related to the production mechanism of children's films: limited funds, plots of circumstance, the production of raw sugar, and the scarcity of stalls. Such a reciprocate formed of a vicious circle, and the end result is that the box office suffered Waterloo and the return is almost zero. This intensifies the story of the domestic film model and character pattern. In the narrative, until the end of the last century, Chinese children's films are more use of single-line narrative. The plot is relatively simple, such as "collapsing brother", it writes the battle story between seven Calabash Boys and the scorpion essence, during which there is more or less the shadow of the Monkey King in "Journey to the West". And this has a lot of similarities with the "Black Cat Sergeant".

\subsection{Character shaping hero}

After the founding of New China, with the gradual establishment of the socialist system, the state-owned private film companies have also brought about a symbolic trend of ideology. Children's image has a clear expression and propaganda of positive political ideology. In other words, the main children's image in the film is a simple, stylized hero. For a long time, the child image of "Little Heroes of Revolution" and "Good Boy" covered the entire burning screen. For example, from the early days of the founding of the movie "The Letter with Feathers ", there appeared a small hero Hai wa. He is no longer the wandering children at the bottom of the old society (such as "San Mao"). This very motivational image, of course, has expressed the belief of people in a particular historical period but has become an ideological symbol. After entering the new period, although the grand narrative of heroization has weakened, its influence still exists. "Bumblebee Brothers", after desperate flame monster pressures in the mountain under the brother of the era, , they defied magical scorpion essence. In the face of tens of thousands of soldiers instigate, "Ginseng Legend" win over the bear ginseng baby who is the era of young heroes. Although this approach to character images caters to the aesthetic expectations of children as true heroes, the little heroes are too stylized so that the small audiences receive simple and flat character image during the long viewing process, which in turn is not consistent with the complexity of the real life. 
Therefore, too much acceptance of this image will also make children's value judgments stagnate on the non-consensual level, which is obviously unfavorable to the growth of children.

\subsection{Creative attitude adult}

For a long time, people think that children's films, like adult-oriented films, are the spiritual products of ideology. Children's movies of this theme are magnified or strengthened indefinitely. Before the reform and opening up, many children's films did not allow the majority of children and adolescents to "cherish memories and sweet memories", that is, allow them to "accept revolutionary education." Into the era of commodity economy, film production began to operate in a commercial mode. Subjecting to the inferiority of its audience and its heavy dependence on filming costs, children's films can only be relied more on government rather than on market-oriented funders, which makes it easy to incorporate into the official-led education structure. This makes the children's movies entertaining decreasing, educational rise, and an important carrier of ideological work. Therefore, politics, morality and so on are still the important requirements of children's film creation. Just look at that there are many primary and secondary school students watching movies, we can understand this. Chinese contemporary children's movies inherit the burden of "enlightenment" from the starting point of creation. "Taking my father to school" is a year-old child who takes on the whole burden of the whole family. The film center's thought is to promote filial piety and more or less demonstrate the instrumentalist creation standpoint.

When children's movies are no longer intended to let the children be entertained and rest. When the film is an important carrier of ideological and political work, the narrative position of the film can not be children but adult. Because only adult teaching will play a role in education for children. Until the end of the century, the creation of children's films is all based on adult's voice. A child who has not done anything in the world must make what adults can do. In the "Sparkling Red Star", the 10-year-old Pan Dongzi wants to attend the party's meeting in secret and learn about the spirit of Zunyi Meeting. This is not only a politicized act but also a naive child as a mature and stable revolutionary. In Happy Hour, the new class teacher is often rebuked in the face of naughty students who love to practice prank. She is also adult in her day-to-day management of students. Huang Xiaoxiao did not study well and she actually supported her parents to test the IQ of the child. Let the child measure IQ, which in itself is disrespectful to the child. However, this will also be promoted in the movie, which reflects that the film's narrative position is completely on the adult side. In contemporary children's movies, especially in the last century's children's films, the expression of children's qualities such as "Fight Back to School Veyron" is very rare, which makes children's movies more or less the feeling of being adults [3].

\section{References}

[1] Yin Xiaoli. Research on the Development of Rural Children's Movies in China in the New Era [D]. Xi'an: Master's Degree in Northwestern University, 2008.

[2] Yao Quanxing children psychology of literature and art [M]. Chongqing: Chongqing Press, 1990.

[3] Li Ying Xin. New Century Chinese children's film narrative research [D]. Changchun: Jilin University master's degree thesis, 2014. 